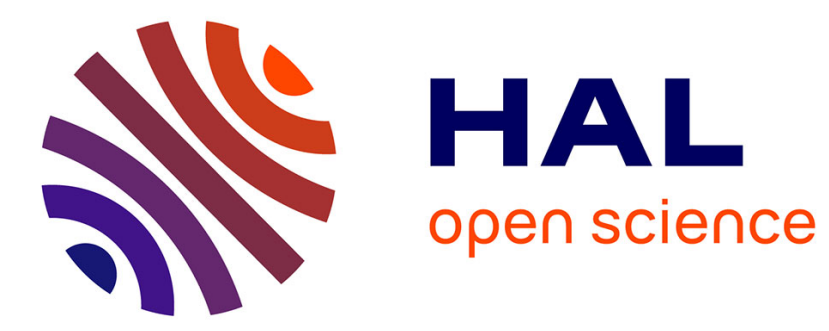

\title{
In situ imaging reveals the biomass of giant protists in the global ocean
}

\author{
Tristan Biard, Lars Stemmann, Marc Picheral, Nicolas Mayot, Pieter \\ Vandromme, Helena Hauss, Gabriel Gorsky, Lionel Guidi, Rainer Kiko, \\ Fabrice Not
}

\section{To cite this version:}

Tristan Biard, Lars Stemmann, Marc Picheral, Nicolas Mayot, Pieter Vandromme, et al.. In situ imaging reveals the biomass of giant protists in the global ocean. Nature, 2016, 532 (7600), pp.504507. 10.1038/nature17652. hal-01324873

\section{HAL Id: hal-01324873 \\ https://hal.sorbonne-universite.fr/hal-01324873}

Submitted on 1 Jun 2016

HAL is a multi-disciplinary open access archive for the deposit and dissemination of scientific research documents, whether they are published or not. The documents may come from teaching and research institutions in France or abroad, or from public or private research centers.
L'archive ouverte pluridisciplinaire HAL, est destinée au dépôt et à la diffusion de documents scientifiques de niveau recherche, publiés ou non, émanant des établissements d'enseignement et de recherche français ou étrangers, des laboratoires publics ou privés. 


\section{In situ imaging reveals the biomass of giant protists in the global ocean.}

Tristan Biard ${ }^{1,2}$, Lars Stemmann ${ }^{2}$, Marc Picheral $^{2}$, Nicolas Mayot $^{2}$, Pieter Vandromme ${ }^{3}$, Helena Hauss ${ }^{3}$, Gabriel Gorsky ${ }^{2}$, Lionel Guidi ${ }^{2}$, Rainer Kiko ${ }^{3} \&$ Fabrice Not $^{1}$.

\footnotetext{
${ }^{1}$ Sorbonne Universités, UPMC Université Paris 06, CNRS, Laboratoire Adaptation et Diversité en Milieu Marin UMR7144, Station Biologique de Roscoff, Roscoff, France. ${ }^{2}$ Sorbonne Universités, UPMC Université Paris 06, CNRS, Laboratoire d'Océanographie de Villefranche (LOV) UMR7093, Observatoire Océanologique, Villefranche-sur-Mer, France. ${ }^{3}$ GEOMAR Helmholtz Centre for Ocean Research Kiel, Wischhofstr. 1-3, 24148 Kiel, Germany.
} 
Planktonic organisms play crucial roles in oceanic food webs and global biogeochemical cycles ${ }^{1,2}$. Most of our knowledge about the ecological impact of large zooplankton stems from research on abundant and robust crustaceans, and in particular $\operatorname{copepods}^{3,4}$. A number of the other organisms that comprise planktonic communities are fragile, and therefore hard to sample and quantify, meaning that their abundances and effects on oceanic ecosystems are poorly understood. Here, using data from a worldwide in situ imaging survey of plankton larger than $600 \mu \mathrm{m}$, we show that a substantial part of the biomass of this size fraction consists of giant protists belonging to the Rhizaria, a super-group of mostly fragile unicellular marine organisms that includes the taxa Phaeodaria and Radiolaria (for example, orders Collodaria and Acantharia). Globally, we estimate that rhizarians in the top $200 \mathrm{~m}$ of world oceans represent a standing stock of 0.089 Pg carbon, equivalent to $5.2 \%$ of the total oceanic biota carbon reservoir ${ }^{5}$. In the vast oligotrophic intertropical open oceans, rhizarian biomass is estimated to be equivalent to that of all other mesozooplankton (plankton in the size range 0.2-20 mm). The photosymbiotic association of many rhizarians with microalgae may be an important factor in explaining their distribution. The previously overlooked importance of these giant protists across the widest ecosystem on the planet ${ }^{6}$ changes our understanding of marine planktonic ecosystems.

Oceanic ecosystems are inhabited by a variety of planktonic organisms spanning a wide size range, from nanometres (viruses) to metres (for example, certain jellyfish). By feeding on small plankton, large zooplankton link primary production to higher trophic levels through the marine food web $^{7}$ and affect carbon export and remineralization to deep oceans by producing fast-sinking particles (fecal pellets and dead bodies) ${ }^{8}$. Most of our knowledge of large zooplankton is based on studies of crustacea such as copepods and euphausiids ${ }^{3,4}$ that are abundant, important for the function of planktonic ecosystems, robust and relatively easy to collect with standard methods such as plankton net tows. As a result, the zooplankton compartment in ecosystem and biogeochemical models is often exclusively represented by the physiological characteristics of copepods ${ }^{9}$.

In contrast, the biology and ecology of planktonic Rhizaria, one of the main eukaryotic super-kingdoms, has been largely unexplored ${ }^{10}$. Rhizarians include small unicellular organisms such as Chlorarachniophyta and heterotrophic Cercozoa along with a wealth of larger cells, ranging in size from a few hundred micrometres to several centimetres and belonging to taxonomic groups such as the Radiolaria, Foraminifera and Phaeodaria. These giant (compared to the size of the vast majority of single-celled plankton) protists are 
predators, but some species are mixotrophs, hosting obligate intracellular microalgal symbionts (photosymbionts) ${ }^{11}$. Most rhizarians produce mineral skeletons of calcium carbonate (Foraminifera) or silicate (polycystine radiolarians) that are often well preserved in marine sediments, making this group a focus for the development of paleoproxies ${ }^{12}$. Others, such as Phaeodaria, Collodaria and Acantharia, possess more delicate skeletons and are not preserved in marine sediment records ${ }^{12,13}$. A number of studies, ranging from sediment trap to environmental molecular surveys ${ }^{15-17}$, have suggested that the Rhizaria are important for present-day oceanic ecosystems. Recent qualitative results from the Tara Oceans expedition demonstrated that the Collodaria, which are mainly large colonial rhizarians, are important components of plankton community structure ${ }^{18}$ and are significantly correlated with downward fluxes of carbon ${ }^{19}$. However, unlike crustacean plankton, which can be easily collected, delicate rhizarians are severely damaged by plankton nets, and other rhizarians, such as Acantharia, eventually dissolve upon preservation in regular fixatives (for example, formalin). Rhizaria are therefore inconsistently sampled ${ }^{13,14,20,21}$ and their global distribution and role in the ecosystem are not well understood. Although they are known to be abundant in specific areas of the oceans ${ }^{14,20,22}$, their contribution to plankton communities has never been assessed on a global scale.

Using a non-destructive in situ imaging system (Underwater Vision Profiler; UVP5) ${ }^{23}$, we quantified the respective contributions of Rhizaria and other zooplankton larger than 600 $\mu \mathrm{m}$ (meso- and macro-zooplankton, excluding smaller components of the plankton community) in a variety of pelagic ecosystems (Fig. 1, Extended Data Table 1 and Extended Data Fig. 1). Worldwide, in the upper $500 \mathrm{~m}$ of the water column, rhizarians comprised on average $33 \%$ of zooplankton observed (Fig. 1). Giant Rhizaria were more abundant in the large inter-tropical oceanic basins, the Mediterranean Sea, and the coastal upwelling off California, where they represented on average $35 \%, 47 \%$ and $81 \%$, respectively, of zooplankton observed (Extended Data Table 2). When converted to carbon biomass, the contribution of Rhizaria was highest between approximately $40^{\circ} \mathrm{N}$ and $20^{\circ} \mathrm{S}$ and was similar to the biomass of meso-zooplankton in the same latitudinal range ${ }^{5}$ (Fig. 2 and Extended Data Table 3). Overall, we estimate that the biomass of Rhizaria larger than $600 \mu \mathrm{m}$ represents a standing stock of $0.089 \mathrm{Pg}$ of carbon in the upper $200 \mathrm{~m}$ of the water column of the world ocean (Table 1). This biologically active carbon reservoir represents $29 \%$ of the combined meso- and macro-zooplankton biomass and $5.2 \%$ of the total oceanic biota carbon standing stock (Table 1). Despite the intrinsic uncertainties associated with such global assessments ${ }^{5}$, these values are consistent with previous estimates based on local studies ${ }^{20}$. 
The four main categories of Rhizaria discriminated in our analysis (Acantharia, Collodaria, Phaeodaria, and other Rhizaria; Extended Data Figs 2-4) exhibited distinct latitudinal biomass distributions (Extended Data Fig. 5). Overall, Phaeodaria and Collodaria were the most important contributors to rhizarian biomass, and Acantharia occurred at consistently low levels. However, most acantharian species are smaller than $600 \mu \mathrm{m}$ and were therefore not quantified by our approach. The highest biomass of Collodaria and Acantharia occurred at low latitudes, whereas the biomass of Phaeodaria and other Rhizaria was more evenly distributed, suggesting that these orders of Rhizaria show distinct ecological preferences. In addition to latitudinal patterns, there was also a significant shift in taxonomic composition with depth (Fig. 3). In the top $100 \mathrm{~m}$ of the water column, photosymbiotic Collodaria contributed most to rhizarian biomass (Fig. 3a). Below, in the twilight zones of the oceans (depth 100-500 m), the asymbiotic phaeodarians were the most important contributors to rhizarian biomass at all latitudes (Fig. 3b). Considering that all Collodaria and most Acantharia investigated so far harbour symbiotic microalgae ${ }^{13,14,24}$, we estimated that these groups typically contribute $0.18 \%(0.17 \%$ for Collodaria and $0.01 \%$ for Acantharia) of total primary production in oligotrophic waters (Extended Data Table 4). Only one study, performed in the oligotrophic Sargasso Sea, has estimated the contribution of Rhizaria to total primary production; this study showed that large photosymbiotic Rhizaria could account for $0.1-0.4 \%$ of total primary production ${ }^{25}$. Even though the contribution of large photosymbiotic Rhizaria to total primary production is rather low, it occurs in the large size fraction, representing primary production directly available to large consumers and thereby shortcutting trophic levels of marine food webs ${ }^{14}$. Our sampling was restricted to organisms $>600 \mu \mathrm{m}$ and therefore excluded the abundant smaller species of rhizarians ${ }^{24}$ and the top $5 \mathrm{~m}$ of the water column, where rhizarians can be highly abundant ${ }^{14,24,25}$. Our estimates of rhizarian abundance and biomass should therefore be considered as conservative and further efforts are required to refine the emerging image of the global rhizarian contribution to biomass, primary productivity and other biogeochemical processes in the oceans.

The previously overlooked contribution of giant rhizarian biomass to plankton communities changes our perception of the oligotrophic tropical oceans. These oceans represent one of the largest ecosystems on the planet, occupying nearly $40 \%$ of the Earth's surface $^{6}$, and are important biomes for the functioning of the biosphere. The use of appropriate tools provides new insights into global zooplankton community structure in the ocean, for instance, demonstrating that the abundance of photosymbiotic Rhizaria declines less markedly than that of other, non-photosymbiotic, zooplankton along a trophic gradient 
(Extended Data Fig. 6), and thus emphasizing the idea that photosymbiosis allows these large organisms to thrive in otherwise hostile oligotrophic environments ${ }^{11,26}$. To date, large rhizarians have been omitted from biogeochemical flux budgets, but they may be efficient vectors for fluxes to the deep ocean via both primary production and vertical flux and could be important components of the biological pump ${ }^{15}$. Along with other cryptic, fragile and transparent creatures such as gelatinous plankton organisms, whose abundance probably remains poorly quantified ${ }^{21}$, rhizarians may thus contribute to carbon budgets in the dark mesopelagic ocean. The measured activity of microbial remineralization in the dark mesopelagic ocean exceeds the estimated carbon input, emphasizing the need to understand the synergy between microbes and large zooplankton to understand the processes that control the oceanic carbon $\operatorname{sink}^{27,28}$. Along with better spatio-temporal descriptions of the occurrence of specific taxa (for example, Phaeodaria in the California coastal upwelling), accurate estimates of poorly known processes such as grazing, growth and biomineralization of Rhizaria and the photophysiology and carbon fixation of their symbionts are required to allow us to include this significant component of the oceanic biota in ecological and biogeochemical models at both local and global scales. 


\section{MAIN TEXT REFERENCES}

1. Behrenfeld, M. J. et al. Climate-driven trends in contemporary ocean productivity. Nature 444, 752-755 (2006).

2. Beaugrand, G., Edwards, M. \& Legendre, L. Marine biodiversity, ecosystem functioning, and carbon cycles. Proc. Natl. Acad. Sci. U.S.A. 107, 10120-10124 (2010).

3. Buitenhuis, E. et al. Biogeochemical fluxes through mesozooplankton. Global. Biogeochem. Cycles. 20, GB2003, http://dx.doi.org/10.1029/2005GB002511 (2006).

4. Rombouts, I. et al. Global latitudinal variations in marine copepod diversity and environmental factors. Proc. R. Soc. B. 276, 3053-3062 (2009).

5. Buitenhuis, E. T. et al. MAREDAT: towards a world atlas of MARine Ecosystem DATa. Earth Syst. Sci. Data. 5, 227-239 (2013).

6. Polovina, J. J., Howell, E. A. \& Abecassis, M. Ocean's least productive waters are expanding. Geophys. Res. Lett. 35, L03618, http://dx.doi.org/10.1029/2007GL031745 (2008).

7. Banse, K. Zooplankton: Pivotal role in the control of ocean production. ICES J. mar. Sci. 52, 265-277 (1995).

8. Wilson, S. E., Ruhl, H. A. \& Smith, K. L. Zooplankton fecal pellet flux in the abyssal northeast Pacific: A 15 year time-series study. Limnol. Oceanogr. 58, 881-892 (2013).

9. Le Quéré, C. et al. Ecosystem dynamics based on plankton functional types for global ocean biogeochemistry models. Glob. Change Biol. 11, 2016-2040 (2005).

10. Burki, F. \& Keeling, P. J. Rhizaria. Curr. Biol. 24, R103-R107, http://dx.doi.org/10.1016/j.cub.2013.12.025 (2014).

11. Stoecker, D. K., Johnson, M. D., de Vargas, C. \& Not, F. Acquired phototrophy in aquatic protists. Aquat. Microb. Ecol. 57, 279-310 (2009).

12. De Wever, P., Dumitrica, P., Caulet, J. P., Nigrini, C. \& Caridroit, M. Radiolarians in the Sedimentary Record (Taylor \& Francis, Amsterdam, 2001).

13. Suzuki, N. \& Not, F. in Marine Protists (eds. Ohtsuka, S., Suzaki, T., Horiguchi, T., Suzuki, N. \& Not, F.) 179-222 (Springer Japan, 2015).

14. Anderson, O. R. Radiolaria (Springer-Verlag, New York, 1983).

15. Lampitt, R. S., Salter, I. \& Johns, D. Radiolaria: Major exporters of organic carbon to the deep ocean. Global. Biogeochem. Cycles. 23, GB1010, http://dx.doi.org/10.1029/2008GB003221 (2009).

16. Fontanez, K. M., Eppley, J. M., Samo, T. J., Karl, D. M. \& DeLong, E. F. Microbial community structure and function on sinking particles in the North Pacific Subtropical Gyre. Front. Microbiol. 6, 469, http://dx.doi.org/10.3389/fmicb.2015.00469 (2015).

17. de Vargas, C. et al. Eukaryotic plankton diversity in the sunlit global ocean. Science 348, 1261605 (2015). 
18. Lima-Mendez, G. et al. Top-down determinants of community structure in the global plankton interactome. Science 348, 1262073 (2015).

19. Guidi, L. et al. Plankton community and gene networks associated with carbon export in the global ocean. Nature (in the press).

20. Dennett, M. R., Caron, D. A., Michaels, A. F., Gallager, S. M. \& Davis, C. S. Video plankton recorder reveals high abundances of colonial Radiolaria in surface waters of the central North Pacific. J. Plankton. Res. 24, 797-805 (2002).

21. Remsen, A., Hopkins, T. L. \& Samson, S. What you see is not what you catch: a comparison of concurrently collected net, Optical Plankton Counter, and Shadowed Image Particle Profiling Evaluation Recorder data from the northeast Gulf of Mexico. Deep-Sea Res. I 51, 129-151 (2004).

22. Stemmann, L. et al. Global zoogeography of fragile macrozooplankton in the upper 100$1000 \mathrm{~m}$ inferred from the underwater video profiler. ICES J. mar. Sci. 65, 433-442 (2008).

23. Picheral, M. et al. The Underwater Vision Profiler 5: An advanced instrument for high spatial resolution studies of particle size spectra and zooplankton. Limnol. Oceanogr. Methods. 8, 462-473 (2010).

24. Michaels, A. F. Vertical distribution and abundance of Acantharia and their symbionts. Mar. Biol. 97, 559-569 (1988).

25. Caron, D. A., Michaels, A. F., Swanberg, N. R. \& Howse, F. A. Primary productivity by symbiont-bearing planktonic sarcodines (Acantharia, Radiolaria, Foraminifera) in surface waters near Bermuda. J. Plankton. Res. 17, 103-129 (1995).

26. Taylor, F. J. R. in The Ecology of Marine Protozoa (ed. Capriulo, G. M.) 323-340 (New York: Oxford University Press, 1990).

27. Herndl, G. J. \& Reinthaler, T. Microbial control of the dark end of the biological pump. Nature Geosci. 6, 718-724 (2013).

28. Giering, S. L. C. et al. Reconciliation of the carbon budget in the ocean's twilight zone. Nature 507, 480-483 (2014).

29. Pesant, S. et al. Tara Oceans Data: A sampling strategy and methodology for the study of marine plankton in their environmental context. Sci. Data 2, 150023, http://dx.doi.org/ 10.1038/sdata.2015.23 (2015).

30. Longhurst, A. Ecological Geography of the Sea (Academic Press, New York, 2010).

31. Moriarty, R. \& O'Brien, T. D. Distribution of mesozooplankton biomass in the global ocean. Earth Syst. Sci. Data. 5, 45-55 (2013). 
Table 1 | Carbon standing stock of giant Rhizaria in the 0-100, 0-200 and 0-500 $\mathrm{m}$ depth layers of the oceans.

Estimates of global giant rhizarian carbon biomass were derived from median values assuming an ocean surface of $3.61 \times 10^{14} \mathrm{~m}^{2}$. Giant rhizarian biomass contributions to global carbon and meso- and macro-zooplankton

\begin{tabular}{|c|c|c|c|c|c|c|c|c|c|}
\hline \multirow[b]{2}{*}{$\begin{array}{l}\text { Depth } \\
\text { layer } \\
(\mathrm{m})\end{array}$} & \multirow{2}{*}{$\begin{array}{l}\text { Number } \\
\text { of } \\
\text { sampling } \\
\text { stations }\end{array}$} & \multicolumn{4}{|c|}{$\begin{array}{l}\text { Rhizarian integrated biomass } \\
\qquad\left(\mathrm{mgC} \mathrm{m}^{-2}\right)\end{array}$} & \multirow{2}{*}{$\begin{array}{c}\text { Global } \\
\text { rhizarian } \\
\text { biomass } \\
(\mathrm{PgC})\end{array}$} & \multicolumn{3}{|c|}{ Contribution to global: } \\
\hline & & Min & Max & Median & IQR & & $\begin{array}{c}\text { Carbon } \\
\text { standing stock }\end{array}$ & $\begin{array}{c}\text { Biomass of } \\
\text { meso- and } \\
\text { macro- } \\
\text { zooplankton }\end{array}$ & $\begin{array}{c}\text { Biomass of } \\
\text { meso- } \\
\text { zooplankton }\end{array}$ \\
\hline $0-100$ & 877 & 0 & 23,910 & 34.43 & 247 & 0.012 & - & - & - \\
\hline $0-200$ & 848 & 0 & 146,400 & 245 & 1,219 & 0.089 & $\begin{array}{c}5.2 \% \\
(0.6-22 \%)\end{array}$ & $\begin{array}{c}29 \% \\
(4-68 \%)\end{array}$ & $\begin{array}{c}31 \% \\
(5-69 \%)\end{array}$ \\
\hline $0-500$ & 694 & 0 & 115,091 & 564 & 1,608 & 0.204 & - & - & - \\
\hline
\end{tabular}

standing stocks were calculated on the basis of the median values for the 0-200 $\mathrm{m}$ depth layer (that is, only matching data available globally) published in ref. 5. The ranges of contribution were computed using the first and third quartiles of rhizarian integrated biomass. IQR, interquartile range. Global biomass estimates are expressed in petagrams of carbon $\left(1 \mathrm{Pg}=10^{15} \mathrm{~g}\right)$. Detailed computational processes are provided in the Methods.

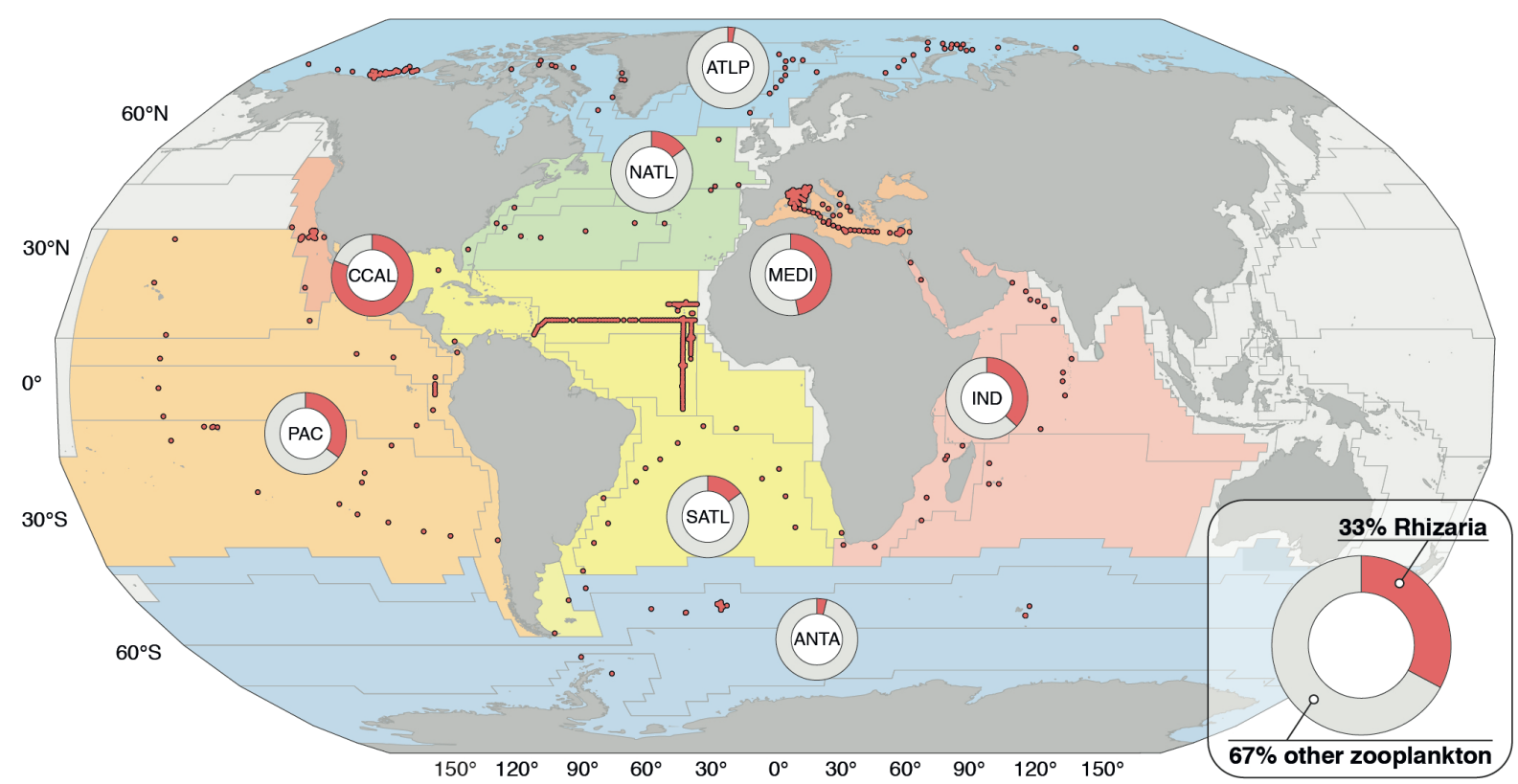

Figure 1 | Worldwide contribution of giant Rhizaria to zooplankton communities $(>600 \mu \mathrm{m})$ in the top $500 \mathrm{~m}$ of the water column. Underwater Vision Profiler sampling stations are represented by red dots (694 stations; Extended Data Table 1). Relative contributions of the depth-integrated abundances are shown for the Rhizaria (red) and other zooplankton (grey) as seen and quantified by UVP5. Bottom right panel, global average contribution for each group considered. Contributions are geographically divided according to Longhurst's Biomes and Provinces ${ }^{30}$ (numerical values are shown in Extended Data Table 2a). Map made with Natural Earth data (http://www.naturalearthdata.com). 


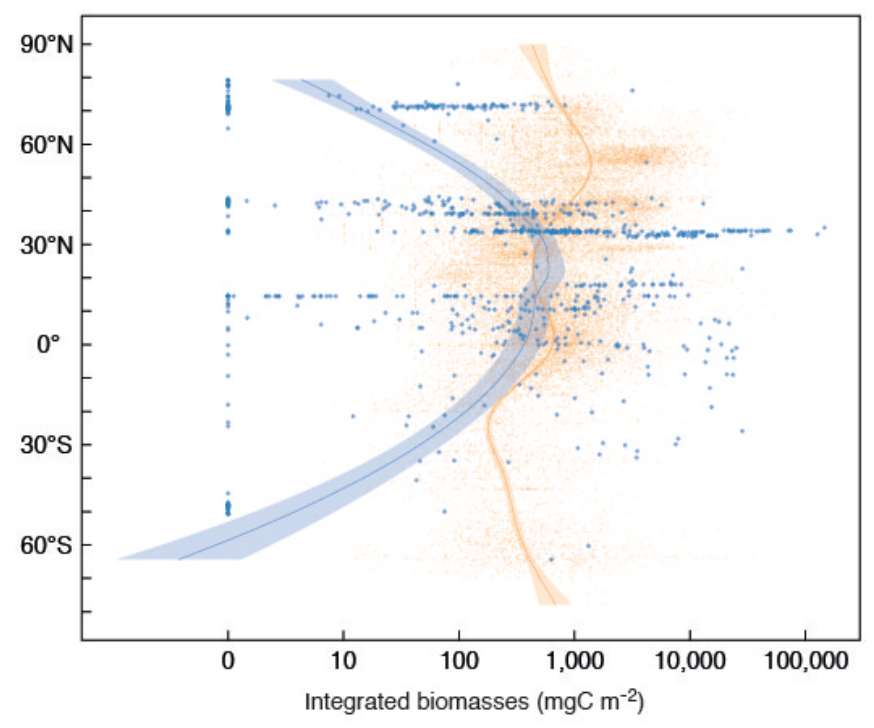

Figure 2 | Latitudinal distribution of depth-integrated biomass (0-200 $\mathrm{m}$ depth) of Rhizaria (blue, in situ optical assessment, this study; 848 sampling stations) and mesozooplankton (orange, plankton net-based assessments ${ }^{31}$; 26,918 samples). Loess regressions with polynomial fitting were computed to illustrate the latitudinal patterns. Shaded areas represent $95 \%$ confidence intervals. Biomass is plotted on a logarithmic scale. 


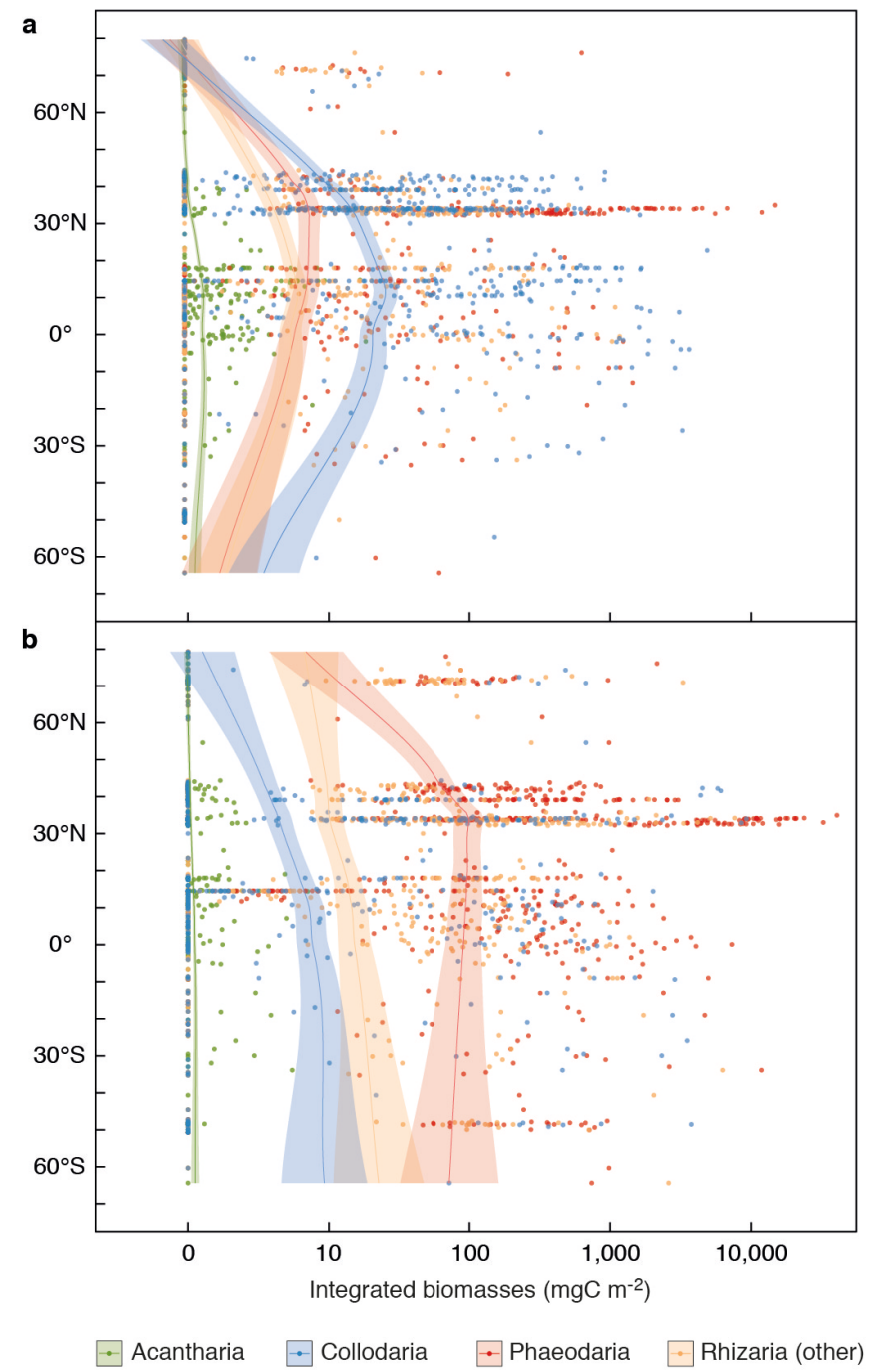

Figure 3 | Latitudinal distribution of depth integrated biomass (mg carbon (mg C) $\mathrm{m}^{-2}$ ) for the different rhizarian taxa identified. a, Biomass integrated in the top $100 \mathrm{~m}$ of the water column (877 sampling stations). b. Biomass integrated between 100 and $500 \mathrm{~m}$ depth (694 sampling stations). Latitudinal trends are represented by computing Loess regressions with a polynomial fitting. Shaded areas represent $95 \%$ confidence intervals. 


\section{METHODS}

Sampling sites. Rhizarian distribution was observed with the Underwater Vision Profiler 5 (UVP5) deployed at 877 stations distributed across all oceans (11 cruises corresponding to 1,454 profiles). Out of these stations, 694 were sampled down to $500 \mathrm{~m}$ depth (Fig. 1 and Extended Data Table 1). Stations encompassed regions with a broad range of oceanographic structures (upwelling, boundary currents, large tropical gyres, etc.) from oligotrophic to eutrophic ecosystems. Sampling effort occurred throughout the year between 2008 and 2013 and covered latitudes from $65^{\circ} \mathrm{S}$ to $75^{\circ} \mathrm{N}$. The majority of stations $(72 \%)$ were sampled between $5^{\circ} \mathrm{S}$ and $40^{\circ} \mathrm{N}$ (Extended Data Fig. 1).

UVP5 deployments and raw data collection. The UVP5 images large plankton (equivalent spherical diameter, ESD $>600 \mu \mathrm{m}$; ref. 23). The UVP5 sampling volume varied from 0.5 to 1 1 and images were recorded every 5 to $20 \mathrm{~cm}$ along vertical profiles, leading to an observed volume of $5 \mathrm{~m}^{3}$ for a $500 \mathrm{~m}$ depth profile. Mounted on a CTD rosette frame, the UVP5 starts recording below $5 \mathrm{~m}$, ultimately leading to an underestimation in the quantification of objects just beneath the sea surface. Images produced by the UVP5 were extracted using the ZooProcess software ${ }^{32}$. For all objects, the major and minor axes of the best fitting ellipses were measured. A computer-assisted method was used to classify all organisms. Image identification was possible for objects larger than $600 \mu \mathrm{m}$. All images (total number $\sim 1.8$ million) were checked by experts to discriminate Rhizaria $(\sim 36,000$ images) from other plankton and detritus. In the present dataset, the maximum ESD recorded was $7 \mathrm{~cm}$ (for a ctenophore); among Rhizaria only, the maximum ESD was $2.5 \mathrm{~cm}$ (for a colonial collodarian) (Extended Data Figure 4). Thereafter, Rhizaria were classified into finer taxonomic levels for all profiles included in this work.

Refining the rhizarian image categories. The entire UVP5 image collection was scanned to infer the diversity of images associated with the Rhizaria. Using taxonomic expertise, ten categories were created and affiliated to known rhizarian taxa (Extended Data Fig. 2). Differences in shapes and grey level were used to distinguish between categories. Phaeodaria were divided into three categories: PhaL, PhaSe and PhaSt. The PhaSe category (Extended Data Fig. 2a) are small grey spheres $(<5 \mathrm{~mm})$ with a tiny black nucleus inside. The black dot is usually found in the centre of the sphere, but its position can vary. The edges of the sphere are darker than the interior (this is an important differentiating criterion from solitary collodarians). PhaSe phaeodarians can be found in aggregates consisting of tens of specimens. The PhaSt category (Extended Data Fig. 2b) are dark grey spheres with a large black or white nucleus. The interior of the sphere is entirely grey, unlike other phaeodarian categories. Tiny 
spines surround the sphere. Images of the PhaL category (Extended Data Fig. 2c) are characterized by multiple long spine-like extensions originating from a dark centre. This dark centre can be a simple black dot or a grey sphere with a dark nucleus. Acantharians (Acn; Extended Data Fig. 2e) possess short- to medium-sized spines surrounding a black centre. The most important criterion to distinguish acantharians from phaeodarians in the PhaL category in the UVP5 images is the symmetry of the spines, which is characteristic of acantharian cells. Collodarians were divided into five categories, including colonial and solitary specimens. Large collodarian colonies (Col; Extended Data Fig. 2j) are easily recognizable by their large size (often over $3 \mathrm{~mm}$; Extended Data Fig. 4) and pigmented appearance. The colony shape is variable and can be spherical, stretched, an assemblage of spheres, and so on. A pale halo often sur- rounds the colony and is helpful for identifying collodarian colonies. The SolGlob category of solitary collodarians (Extended Data Fig. 2i) are large, spherical-to-oval organisms with a homogenous grey (or dark-grey) surface. The central sphere is surrounded by a blurry halo generated by a network of pseudopodial extensions. The SolB and SolG categories of solitary collodarians (Extended Data Fig. 2f, h) are large spherical organisms with a dense central part (black/dark grey and grey, respectively). A gradient of grey is observed from the central part to the outer part of the cell. As the outermost part of this halo is almost transparent, the edges of the organism are not always visible. The grey level of the central part is the main distinguishing criterion between the two categories. The last category of solitary collodarians (SolF; Extended Data Fig. 2g) also comprises large spherical organisms with a grey central part surrounded by a dark-grey fuzzy structure. A gradient of grey is observed from the central part to the outer part of the cell. The fuzzy structure around the central part is the main criterion that distinguishes these organisms from other solitary categories. Not all rhizarian images fitted into the categories defined above. The category Rhiz (Extended Data Fig. 2d) comprised rhizarians that could not be precisely fitted into the previous categories, such as Foraminifera, which also belong to the super-group Rhizaria but mostly fall below the size threshold of our camera system.

Qualitative calibration of the newly defined categories was performed on plankton samples collected gently in Villefranche-sur-Mer bay (France, 43⒋ $41^{\prime} 10^{\prime \prime} \mathrm{N}, 7^{\circ} 19^{\prime} 00^{\prime \prime} \mathrm{E}$ ) using a Regent net (680 $\mu \mathrm{m}$ mesh size) and off California (Californian Current Ecosystem) using a $333 \mu \mathrm{m}$ mesh size plankton net hauled at a maximum speed of $0.5 \mathrm{~m} \mathrm{~s}^{-1}$ to minimize damage to the specimens. Live rhizarian specimens (Collodaria and Phaeodaria) were handpicked from the samples and then transferred into $0.2 \mu \mathrm{m}$ filtered seawater. Each specimen was identified and photographed. The UVP5 was immersed in an aquarium filled 
with $0.2 \mu \mathrm{m}$ filtered seawater. Freshly isolated specimens were dropped one by one on top of the illuminated volume of water to capture in situ images. Comparison between ex situ and in situ images confirmed the categories defined for the UVP5 image collection (Extended Data Fig. 3).

Data analysis. Analyses of rhizarian data included five steps: (i) vertical binning of each profile into four depth layers $(0-100 \mathrm{~m}, 0-200 \mathrm{~m}, 100-500 \mathrm{~m}$ and 0-500 m). These layers were selected on the basis of photic properties and availability of published matching plankton datasets for comparison and to maximize the number of sampling stations considered in our dataset. Then, for each depth layer, we calculated (ii) the integrated abundance and (iii) biomass of all Rhizaria, and (iv) the primary production by photosymbiotic Rhizaria. (v) The results were averaged according to the different biogeochemical regions. All analyses were performed in R (ref. 33) with the package ggplot2 (ref. 34).

(i) For each sampling station with several vertical profiles, all profiles were summed to construct one single profile. Stations were divided into two categories according to maximum deployment depth. The UVP5 recorded images down to $100 \mathrm{~m}$ depth in 877 stations, and down to $500 \mathrm{~m}$ depth in 694 stations (Extended Data Table 1). Sample volume was on average $1.74 \pm 0.59 \mathrm{~m}^{3}$ between 0 and $100 \mathrm{~m}$ depth and $2.95 \pm 0.81 \mathrm{~m}^{3}$ between 100 and 500 $\mathrm{m}$ depth.

(ii) Mean integrated abundances and relative contributions of Rhizaria were calculated for the 0-500 m layer. To assess the contribution of Rhizaria to the entire zooplankton community, the abundance of other planktonic groups identified during the image process was computed. All other zooplankton imaged by the UVP5 were distinguished from non-living particles by semi-automatic annotation validated by experts; these organisms included copepods, crustaceans (shrimp-like, amphipod, cladoceran), gelatinous zooplankton (jellyfishes, ctenophores, siphonophores, salps), chaetognaths, appendicularia, molluscs, annelids and fish larvae. Other particles (detritus, aggregates, etc.) and phytoplankton (large diatoms, Trichodesmium, etc.) were removed from the computation.

(iii) Biomass estimations for the different rhizarian categories were inferred from organism measurements (major and minor axes of the best fitting ellipse) generated during ZooProcess image processing. These axes were used for biomass calculation instead of the Equivalent Spherical Diameter (ESD), as the use of the latter leads to an overestimation of biomass for large and elongated organisms (such as long colonial collodarians). Biovolume was first calculated from geometric shapes for all categories except colonial collodarians: 
spheres for Acantharia, prolate ellipsoid for all other categories (Extended Data Table 3). Areas $(A \mathrm{e})$ of a prolate ellipsoid were determined for colonial collodarians as follows:

$$
A_{e}=2 \pi \cdot\left(\frac{\text { minor }}{2}\right)^{2}+\frac{2 \pi \cdot\left(\frac{\text { Major }}{2} \cdot \frac{\text { minor }}{2}\right)}{e} \cdot \arcsin (e)
$$

where $e$ is the eccentricity of an ellipse:

$$
e=\frac{\sqrt{\left(\frac{\text { Major }}{2}\right)^{2}-\left(\frac{\text { minor }}{2}\right)^{2}}}{\left(\frac{\text { Major }}{2}\right)}
$$

Biovolumes and surface areas were then converted to biomass using carbon conversion factors from the literature ${ }^{20,35,36}$ (Extended Data Table 3).

(iv) Primary production of photosymbiotic rhizarians was estimated individually for all Acantharia and Collodaria observed between 0 and $500 \mathrm{~m}$ depth. While all collodarian species investigated have been described as photosymbiotic ${ }^{13,14}$, the vast majority of large acantharian specimens found in the upper water column are known to harbour symbionts ${ }^{24,25}$. Individual primary production (iPP) was estimated for each photosymbiotic rhizarian as a function of the biovolume ${ }^{25}$ :

$$
\log (\mathrm{iPP})=0.62 \cdot \log (\text { Biov })-4.33
$$

where Biov is the biovolume of the holobiont estimated from a prolate ellipsoid.

Assuming a reference temperature (Tref) of $23.5^{\circ} \mathrm{C}$ (ref. 25), we applied a $Q 10$ temperature coefficient of 1.88 (ref. 37) to correct for temperature effects on photosynthetic production and yield temperature-corrected individual primary production (iPPT):

$$
\mathrm{iPP}_{\mathrm{T}}=\mathrm{iPP} \cdot\left[1.88\left(\frac{T_{\mathrm{ref}}-T_{\mathrm{ctd}}}{10}\right)\right]^{-1}
$$

where $T_{\text {ctd }}$ is the in situ temperature measured by the CTD at the depth of each organism.

The $490 \mathrm{~nm}$ light attenuation coefficient $K_{\mathrm{d}}(490)\left(\mathrm{m}^{-1}\right)$ and photosynthetic active radiation (PAR; mol photons per $\mathrm{m}^{2}$ per day) were used to estimate the available instantaneous radiation at depth. Satellite-derived average daily PAR, net primary production (NPP), chlorophyll $a$ (Chl $\left.a_{\text {sat }}\right)$ and $K_{\mathrm{d}}(490)$ (8-day averages at 4-km resolution) were downloaded from the Oregon University database (http://www.science.oregonstate.edu/ocean.productivity/ ). Average values for each station were calculated for the position occupied $\pm 0.1^{\circ}$ if the occupation date fell within the 8-day window of the satellite observation. The PAR attenuation coefficient $K_{\mathrm{d}}(\mathrm{PAR})$ was calculated according to $\mathrm{Morel}^{38}$ as:

$$
K_{\mathrm{d}}(\mathrm{PAR})=0.0864+0.884 K_{\mathrm{d}}(490)-0.00137\left[K_{\mathrm{d}}(490)\right]^{-1}
$$


The average instantaneous radiation available at the surface (iPAR in $\mu$ mol photons $\mathrm{m}^{2}$ per $\left.\mathrm{s}\right)$ during daytime was calculated as:

$$
\operatorname{iPAR}_{\mathrm{s}}=\left(\frac{\mathrm{PAR}}{\text { daylength }}\right) / 3,600 \cdot 10^{6}
$$

with daylength in h per day. From this data, the instantaneous radiation available at a specific depth z $\left(\mathrm{iPAR}_{\mathrm{d}}\right)$ was calculated as:

$$
\mathrm{iPAR}_{\mathrm{d}}=e^{\left(K_{\mathrm{d}}(\mathrm{PAR}) \cdot z\right)} \cdot \mathrm{iPAR}_{\mathrm{s}}
$$

The primary productivity measurements for radiolarians and acantharians used in equation (3) were conducted at surface light conditions nearby Bermuda ${ }^{25}$. These conditions are likely to be saturating light conditions for symbiotic rhizarians ${ }^{39}$. Very little photophysiological information is available for photosymbiotic Rhizaria. To calculate the decrease in primary productivity with decreasing light availability, the fraction of primary productivity possible at a given $\mathrm{iPAR}\left(\mathrm{fPP}_{\mathrm{iPAR}}\right)$ was calculated from the light saturation intensity $\left(I_{\mathrm{k}}=165 \mu \mathrm{mol}\right.$ photons $\mathrm{m}^{2}$ per $\left.\mathrm{s}\right)$ observed for Globigerinoides sacculifer, a photosymbiotic planktonic Foraminifera ${ }^{39}$ according to the hyperbolic tangent function for the light dependency of photosynthesis in marine phytoplankton ${ }^{40}$ as:

$$
\mathrm{fPP}_{\mathrm{iPAR}}=\tanh \left(\frac{\mathrm{iPAR}_{\mathrm{d}}}{I_{\mathrm{k}}}\right)
$$

The individual primary productivity at a given depth was then calculated as:

$$
\mathrm{iPP}=\mathrm{iPP}_{\mathrm{T}} \cdot \mathrm{fPP}_{\mathrm{iPAR}}
$$

Finally, given the paucity of information available, it should be noted that we used sizeprimary productivity relations for acantharians and collodarians from just one study ${ }^{25}$ and the dependency of photosynthesis on light availability from a planktonic Foraminifera for these calculations.

(v) Each UVP5 station was finally affiliated to one of 33 Longhurst's biogeochemical provinces and assembled in the biomes defined by Longhurst ${ }^{30}$ (Extended Data Tables 1 and 2). Only 29 stations were sampled within Longhurst's coastal provinces (FKLD, BRAZ, CARM, CHIL, GUIA, NWCS, ARAB, REDS and EAFR). The bottom depth at these stations was always more than $500 \mathrm{~m}$ and they were not located on the continental shelf or continental slope. All these coastal province stations were therefore merged with their adjacent oceanic biomes, and the Antarctic Biome included both the Antarctic Polar Biome and the Antarctic Westerly Winds Biome. The merging of sampling stations located in Longhurst's coastal provinces with their adjacent biomes did not affect the contribution of Rhizaria to zooplankton communities in these biomes. Indeed, when considered separately, the average 
Rhizaria contribution for coastal provinces reached similar values as for the global dataset (33.81\%). Two provinces, the Mediterranean Sea (MEDI) and the California Upwelling Coastal (CCAL) provinces, were treated separately from their respective biomes (Atlantic Coastal and Pacific Coastal biomes) because both were densely sampled and showed high rhizarian abundances compared to the other provinces in the same biomes.

Global estimates. Global estimates of rhizarian biomass were computed for three different layers (Table 1) assuming an ocean surface of $3.61 \times 10^{14} \mathrm{~m}^{2}$. All estimates were derived from median biomass values to prevent overestimates using mean values, the latter being highly influenced by locally high biomass values (for example, the California Current). Low and high estimates of global rhizarian biomass were computed using the first and third quartile, respectively. We compared the global rhizarian biomass to independent data on the global average estimates of meso- and macro-zooplankton biomass in the first $200 \mathrm{~m}$ of the oceans $^{5}$. The contribution of Rhizaria to global plankton biomass was established using 11 different plankton functional types (PFTs) ${ }^{5}$, including autotrophic and heterotrophic PFTs. The median derived biomass for each plankton group was considered in the top $200 \mathrm{~m}$ and summed to provide an estimate of the plankton carbon standing stock. Despite uncertainties inherent to any global estimates (for example, carbon conversion factors, sampling coverage; ref. 5) we intended to provide a conservative contribution of Rhizaria to the different plankton components. The relative contribution of global rhizarian biomass to global plankton carbon standing stock was therefore calculated as the global rhizarian biomass divided by the sum of the published reference estimate for global plankton biomass ${ }^{5}$ and the global rhizarian biomass.

Possible impact of sampling coverage on rhizarian biomass distribution pattern. The global patterns observed in this study are inevitably associated with the sampling effort and geographic coverage (Extended Data Fig. 1). Some oceanic areas and/or seasons were more intensely sampled than others, creating heterogeneity in the dataset. For instance, the Mediterranean Sea and the California Current were sampled intensely. Although we sampled 33 of 51 Longhurst's provinces, our spatial coverage was partial. To assess the possible influence of sampling coverage on latitudinal pattern of rhizarian biomass distribution, we used the sample function (implemented in R version 3.2.0) to obtain a random subset of our dataset and tested the latitudinal pattern of this dataset against the original dataset. We selected five latitude intervals of $30^{\circ}$ (between $90^{\circ} \mathrm{N}$ and $60^{\circ} \mathrm{S}$ ) and randomly extracted 20 sampling stations from each with bootstrap resampling. The difference between the resampled dataset ( $n=100$ sampling stations) and the original entire dataset ( $n=694$ sampling stations) 
was tested with a non-parametric Mann-Whitney $U$-test and no significant difference was observed $(P=0.155)$.

Data accessibility. The data described herein are publicly available at PANGEA ${ }^{41-43}$.

\section{METHODS REFERENCES}

32. Gorsky, G. et al. Digital zooplankton image analysis using the ZooScan integrated system. J. Plankton. Res. 32, 285-303 (2010).

33. R Core Team, R: A Language and Environment for Statistical Computing. R Foundation for Statistical Computing (2014).

34. Wickham, H. ggplot2: Elegant Graphics for Data Analysis (Springer Science \& Business Media, New York, 2009).

35. Michaels, A. F., Caron, D. A., Swanberg, N. R., Howse, F. A. \& Michaels, C. M. Planktonic sarcodines (Acantharia, Radiolaria, Foraminifera) in surface waters near Bermuda: abundance, biomass and vertical flux. J. Plankton. Res. 17, 131-163 (1995).

36. Beers, J. R. \& Stewart, G. L. in The ecology of the plankton off La Jolla, California, in the period April through September, 1967, Part VI (eds Strickland, J. D. H., Solarzano, L. \& Eppley, R. W.) 17, 67-87 (Bull. Scripps Inst. Oceanogr. 1970).

37. Bissinger, J. E., Montagnes, D. J. S., Sharples, J. \& Atkinson, D. Predicting marine phytoplankton maximum growth rates from temperature: Improving on the Eppley curve using quantile regression. Limnol. Oceanogr. 53, 487-493 (2008).

38. Morel, A. Examining the consistency of products derived from various ocean color sensors in open ocean (Case 1) waters in the perspective of a multi-sensor approach. Remote Sens. Environ. 111, 69-88 (2007).

39. Jørgensen, B. B., Erez, J., Revsbech, N. P. \& Cohen, Y. Symbiotic photosynthesis in a planktonic foraminiferan, Globigerinoides sacculifer (Brady), studied with microelectrodes. Limnol. Oceanogr. 30, 1253-1267 (1985).

40. Jassby, A. D. \& Platt, T. Mathematical formulation of the relationship between photosynthesis and light for phytoplankton. Limnol. Oceanogr. 21, 540-547 (1976).

41. Biard, T. et al. Abundance of large protists from the Infrakingdom Rhizaria in the global ocean. PANGAEA http://dx.doi.org/10.1594/PANGAEA.858136 (2016).

42. Biard, T. et al. Biomass of large protists from the Infrakingdom Rhizaria in the global ocean. PANGAEA http://dx.doi.org/10.1594/PANGAEA.858156 (2016).

43. Biard, T. et al. Environmental context of a compilation about the distribution of large protists from the Infrakingdom Rhizaria in the global ocean. PANGAEA http://dx.doi.org/10.1594/PANGAEA.858158 (2016). 
44. Field, C. B., Behrenfeld, M. J., Randerson, J. T. \& Falkowski, P. Primary production of the biosphere: Integrating terrestrial and oceanic components. Science 281, 237-240 (1998).

45. Richardson, T. L. \& Jackson, G. A. Small Phytoplankton and Carbon Export from the Surface Ocean. Science 315, 838-840 (2007).

\section{End Notes}

Acknowledgments. Thanks to J.-O. Irisson for help with the $\mathrm{R}$ language and statistical analysis and I. Probert and J. Dolan for comments and English proofreading. The following people were involved in cruise organization: T. Moutin (BOUM), M. Landry and M. Ohman (CCE LTER), S. Blain (KEOPS II), V. Smetacek and W. Naqvi (LOHAFEX), J. Karstensen (M96), M. Babin (Malina), L. Coppola (Moose GE), P. Brandt (MSM22) and M. Visbeck (MSM23). The following people were involved in plankton image sorting: L. Burdorf (CNRS LOV), C. Desnos (CNRS LOV), A. Forest (Tackuvit), G. IdAoud (CNRS LOV), M. P. Jouandet (MIO Pytheas), J. Poulain (CEA), J. Baptiste Romagnan (CNRS LOV), F. Roullier (CNRS LOV), S. Searson (CNRS LOV), B. Serranito (EBMA-PROTEE) and N. Vasset (CNRS LOV). This study is a contribution from the CCE-LTER program, supported by the U.S. National Science Foundation. For the Tara Oceans expedition we thank the CNRS (in particular Groupement de Recherche GDR3280), European Molecular Biology Laboratory (EMBL), Genoscope/CEA, VIB, Stazione Zoologica Anton Dohrn, UNIMIB, Fund for Scientific Research - Flanders, Rega Institute, KU Leuven and the French Ministry of Research. We also thank A. Bourgois and E. Bourgois, the Veolia Environment Foundation, Région Bretagne, Lorient Agglomération, World Courier, Illumina, the EDF Foundation, FRB, the Prince Albert II de Monaco Foundation, the Tara schooner and its captains and crew. We are also grateful to the French Ministry of Foreign Affairs for supporting the expedition and to the countries who granted sampling permission. Tara Oceans would not exist without continuous support from 23 institutes (http://oceans.taraexpeditions.org). The authors further declare that all data reported herein are fully and freely available from the date of publication, with no restrictions, and that all of the samples, analyses, publications, and ownership of data are free from legal entanglement or restriction of any sort by the various nations in whose waters the Tara Oceans expedition sampled. Data described herein are available at PANGAEA (http://doi.pangaea. de/10.1594/PANGAEA.842227), and the data release policy regarding future public release of Tara Oceans data is described in ref. 29. Funding was from DESIR project Emergence-UPMC from Université Pierre et Marie Curie, JST-CNRS exchange program, CHAIRE CNRS/UPMC Vision, Investissements d'Avenir' programmes OCEANOMICS (ANR-11-BTBR-0008), DFG through SFB754 (GEOMAR and Kiel University) and Future Ocean (Kiel University and GEOMAR). This article is contribution number 38 from Tara Oceans.

Author Contributions. F.N. and L.S. designed the study. M.P., T.B., R.K., P.V., H.H., N.M. and G.G. acquired and extracted raw data. T.B. produced the morphological classification of the rhizarian UVP images. T.B., L.S. and L.G. performed statistical analyses. R.K. and T.B. 
calculated the primary production contributions. F.N. and T.B. wrote the manuscript and produced display items. L.S., R.K., L.G., M.P., H.H. and G.G. discussed the results and commented on the manuscript.

\section{Author Information}

Reprints and permissions information is available at www.nature.com/reprints. The authors declare no competing financial interests. Readers are welcome to comment on the online version of the paper. Correspondence and requests for materials should be addressed to L.S. (stemmann@obs-vlfr.fr) or F.N. (not@sb-roscoff.fr). 
Extended Data Figures Legends:

Extended Data Table 1 | Sampling cruise information, number of stations sampled, and of UVP5 deployments (for example profiles) used to generate the dataset analyzed in this study.

\begin{tabular}{|c|c|c|c|c|c|c|c|}
\hline \multirow{2}{*}{$\begin{array}{l}\text { Sampling } \\
\text { Cruise } \\
\text { Name }\end{array}$} & \multirow{2}{*}{ Year } & \multirow{2}{*}{$\begin{array}{c}\text { Chief } \\
\text { Scientists }\end{array}$} & \multirow{2}{*}{ Biomes } & \multicolumn{2}{|c|}{$(0-100 \mathrm{~m})$} & \multicolumn{2}{|c|}{$(100-500 \mathrm{~m})$} \\
\hline & & & & $\begin{array}{l}\text { Sampling } \\
\text { Stations }\end{array}$ & Profiles & $\begin{array}{l}\text { Sampling } \\
\text { Stations }\end{array}$ & Profiles \\
\hline BOUM & 2008 & T. Moutin & $\begin{array}{l}\text { Mediterranean Sea* } \\
\quad \text { (MEDI) }\end{array}$ & 183 & 183 & 151 & 151 \\
\hline KEOPS II & 2011 & S. Blain & $\begin{array}{l}\text { Antarctic Biome } \\
\text { (ANTA) }\end{array}$ & 7 & 7 & 7 & 7 \\
\hline LOHAFEX & 2009 & V. Smetacek & $\begin{array}{l}\text { Antarctic Biome } \\
\text { (ANTA) }\end{array}$ & 27 & 27 & 21 & 21 \\
\hline CCE-LTER & 2008 & $\begin{array}{l}\text { M. Landry } \\
\text { M. Ohman }\end{array}$ & $\begin{array}{l}\text { California Upwelling Coastal }{ }^{*} \\
\text { (CCAL) }\end{array}$ & 75 & 75 & 58 & 58 \\
\hline M96 & 2013 & J. Karstensen & $\begin{array}{l}\text { Atlantic Trade Wind Biome } \\
\text { (SATL) }\end{array}$ & 60 & 77 & 58 & 59 \\
\hline MALINA & 2009 & M. Babin & $\begin{array}{l}\text { Atlantic Polar Biome } \\
\text { (ATPL) }\end{array}$ & 119 & 119 & 54 & 54 \\
\hline $\begin{array}{l}\text { MOOSE- } \\
\quad \text { GE }\end{array}$ & 2012 & L. Coppola & $\begin{array}{l}\text { Mediterranean Sea* } \\
\text { (MEDI) }\end{array}$ & 87 & 87 & 79 & 79 \\
\hline MSM22 & 2012 & P. Brandt & $\begin{array}{c}\text { Atlantic Trade Wind Biome } \\
\text { (SATL) }\end{array}$ & 108 & 108 & 80 & 80 \\
\hline MSM23 & 2012 & M. Visbeck & $\begin{array}{c}\text { Atlantic Trade Wind Biome } \\
\text { (SATL) }\end{array}$ & 45 & 45 & 45 & 45 \\
\hline \multirow{8}{*}{$\begin{array}{l}\text { Tara } \\
\text { Oceans }\end{array}$} & 2009 & \multirow{8}{*}{$\begin{array}{c}\text { Tara Oceans } \\
\text { Consortium }\end{array}$} & $\begin{array}{l}\text { Mediterranean Sea* } \\
\quad \text { (MEDI) }\end{array}$ & 27 & 46 & 24 & 29 \\
\hline & 2010 & & $\begin{array}{l}\text { Indian Ocean Trade Wind Biome } \\
\text { (IND) }\end{array}$ & 23 & 94 & 22 & 80 \\
\hline & 2010 & & $\begin{array}{c}\text { Atlantic Trade Wind Biome } \\
\text { (SATL) }\end{array}$ & 16 & 82 & 14 & 55 \\
\hline & 2011 & & $\begin{array}{l}\text { Antarctic Biome } \\
\text { (ANTA) }\end{array}$ & 3 & 6 & 3 & 5 \\
\hline & 2011 & & $\begin{array}{l}\text { Pacific Trade Wind Biome } \\
\text { (PAC) }\end{array}$ & 34 & 218 & 33 & 140 \\
\hline & 2011 & & $\begin{array}{l}\text { California Upwelling Coastal }{ }^{*} \\
\text { (CCAL) }\end{array}$ & 4 & 30 & 4 & 26 \\
\hline & 2012 & & $\begin{array}{c}\text { Atlantic Trade Wind Biome } \\
\text { (SATL) }\end{array}$ & 2 & 17 & 2 & 13 \\
\hline & 2012 & & $\begin{array}{l}\text { Atlantic Westerly Winds Biome } \\
\text { (NATL) }\end{array}$ & 12 & 92 & 12 & 73 \\
\hline \multirow{3}{*}{ Tara Arctic } & 2013 & \multirow{2}{*}{$\begin{array}{l}\text { Tara Oceans } \\
\text { Consortium }\end{array}$} & $\begin{array}{l}\text { Atlantic Westerly Winds Biome } \\
\text { (NATL) }\end{array}$ & 1 & 9 & 1 & 9 \\
\hline & 2013 & & $\begin{array}{c}\text { Atlantic Polar Biome } \\
\text { (ATPL) }\end{array}$ & 44 & 132 & 26 & 72 \\
\hline & & Total & & 877 & 1,454 & 694 & 1,056 \\
\hline
\end{tabular}

Biogeochemical Biomes are defined according to ref. $30 .{ }^{*}$ This province was treated separately from its biome since it showed a strong pattern in rhizarian abundance compared to the other provinces in the same biome. 
Extended Data Table 2 | Respective contributions of Rhizaria and other zooplankton abundances to the zooplankton community $(>600 \mu \mathrm{m})$ integrated for the upper 0-500 $\mathrm{m}$ of the water column.

a

\begin{tabular}{|c|c|c|c|c|c|}
\hline \multirow{2}{*}{$\begin{array}{l}\text { Longhurst's } \\
\text { Biogeochemical } \\
\text { Biomes }\end{array}$} & \multirow{2}{*}{$\begin{array}{l}\text { Number of } \\
\text { sampling } \\
\text { stations }\end{array}$} & \multirow{2}{*}{$\begin{array}{l}\text { Number of } \\
\text { profiles }\end{array}$} & \multirow{2}{*}{$\begin{array}{l}\text { Zooplankton community } \\
\text { / Sampling station } \\
\text { (ind } \mathrm{m}^{-2} \text { ) }\end{array}$} & \multicolumn{2}{|c|}{$\begin{array}{c}\text { Contribution to zooplankton community } \\
(\%)\end{array}$} \\
\hline & & & & Rhizaria & Other zooplankton \\
\hline $\begin{array}{l}\text { Atlantic Polar Biome } \\
\text { (ATLP) }\end{array}$ & 80 & 126 & 206,905 & 3 & 97 \\
\hline $\begin{array}{l}\text { Antarctic Biome } \\
\text { (ANTA) }\end{array}$ & 31 & 33 & 126,802 & 4 & 96 \\
\hline $\begin{array}{l}\text { Atlantic Westerly } \\
\text { Winds Biome } \\
\text { (NATL) }\end{array}$ & 13 & 82 & 434,501 & 15 & 85 \\
\hline $\begin{array}{l}\text { Atlantic Trade Wind } \\
\text { Biome } \\
\text { (SATL) }\end{array}$ & 199 & 252 & 273,721 & 15 & 85 \\
\hline $\begin{array}{l}\text { Pacific Trade Wind } \\
\text { Biome } \\
\text { (PAC) }\end{array}$ & 33 & 140 & 354,035 & 35 & 65 \\
\hline $\begin{array}{l}\text { Indian Ocean Trade } \\
\text { Wind Biome } \\
\text { (IND) }\end{array}$ & 22 & 80 & 68,911 & 37 & 63 \\
\hline $\begin{array}{l}\text { Mediterranean Sea* } \\
\text { (MEDI) }\end{array}$ & 254 & 259 & 21,269 & 47 & 53 \\
\hline $\begin{array}{c}\text { California Upwelling } \\
\text { Coastal }^{*} \\
\text { (CCAL) }\end{array}$ & 62 & 84 & 556,582 & 81 & 19 \\
\hline \multicolumn{4}{|c|}{ Average proportion } & 33 & 67 \\
\hline
\end{tabular}

b

\begin{tabular}{cccc}
\hline \multirow{2}{*}{$\begin{array}{c}\text { Sampling station } \\
\text { category }\end{array}$} & $\begin{array}{c}\text { Number of } \\
\text { sampling } \\
\text { stations }\end{array}$ & \multicolumn{2}{c}{$\begin{array}{c}\text { Contribution to zooplankton community } \\
\text { (\%) }\end{array}$} \\
\hline 'Gyre' & 144 & Rhizaria & Other zooplankton \\
'Non-gyre' & 550 & 17 & 83 \\
\hline Oligotrophic area & 273 & 17 & 83 \\
\hline Non-oligotrophic area & 408 & 21 & 79 \\
\hline
\end{tabular}

a, Contributions in the different Longhurst's biogeochemical biomes. b, Contributions computed by removing sampling stations from the California coastal upwelling, for gyre/non-gyre and oligotrophic/non-oligotrophic (Chla $<0.1 \mathrm{mg} \mathrm{m}^{-3}$; ref. 44) categories. *This province was treated separately from its biome since it showed a strong pattern in rhizarian abundance compared to the other provinces in the same biome. 
Extended Data Table 3 | Carbon conversion factors used to assess biomass for the rhizarian categories discriminated.

\begin{tabular}{|c|c|c|c|}
\hline Category & Parameter estimated & Carbon conversion factors* & $\begin{array}{c}\text { Conversion factors } \\
\text { references }\end{array}$ \\
\hline $\begin{array}{l}\text { Acantharia } \\
\text { (Acn) }\end{array}$ & Biovolume & $0.0026 \mathrm{mgC} \mathrm{mm}^{-3}$ & (40) \\
\hline $\begin{array}{l}\text { Collodaria_colony } \\
\text { (Col) }\end{array}$ & Surface Area & $133 \mathrm{ngC} \mathrm{cc}^{-1}$ & $(20,40)$ \\
\hline $\begin{array}{l}\text { Collodaria_solitary_black } \\
\text { (SolB) }\end{array}$ & Biovolume & $0.28 \mathrm{mgC} \mathrm{mm}^{-3}$ & (40) \\
\hline $\begin{array}{l}\text { Collodaria_solitary_fuzzy } \\
\text { (SolF) }\end{array}$ & Biovolume & $0.28 \mathrm{mgC} \mathrm{mm}^{-3}$ & (40) \\
\hline $\begin{array}{l}\text { Collodaria_solitary_globule } \\
\text { (SolGlob) }\end{array}$ & Biovolume & $0.009 \mathrm{mgC} \mathrm{mm}^{-3}$ & (40) \\
\hline $\begin{array}{l}\text { Collodaria_solitary_grey } \\
\text { (SolG) }\end{array}$ & Biovolume & $0.28 \mathrm{mgC} \mathrm{mm}^{-3}$ & (40) \\
\hline $\begin{array}{l}\text { Phaeodaria_leg } \\
\text { (PhaL) }\end{array}$ & Biovolume & $0.08 \mathrm{mgC} \mathrm{mm}^{-3}$ & (41) \\
\hline $\begin{array}{l}\text { Phaeodaria_sphere_eye } \\
\text { (PhaSe) }\end{array}$ & Biovolume & $0.08 \mathrm{mgC} \mathrm{mm}^{-3}$ & (41) \\
\hline $\begin{array}{l}\text { Phaeodaria_sphere_thorn } \\
\text { (PhaSt) }\end{array}$ & Biovolume & $0.08 \mathrm{mgC} \mathrm{mm}^{-3}$ & (41) \\
\hline $\begin{array}{l}\text { Rhizaria_other } \\
\text { (Rhiz) }\end{array}$ & Biovolume & $0.08 \mathrm{mgC} \mathrm{mm}^{-3}$ & (41) \\
\hline
\end{tabular}

* Carbon contents are expressed as a function of the biovolume $\left(\mathrm{mg} \mathrm{C} \mathrm{mm}^{-3}\right)$ or as a function of the number of central capsules $(\mathrm{cc})$ in colonial collodarian.

Extended Data Table 4 | Net primary production of photosymbiotic giant rhizarians (Collodaria and Acantharia) and their contribution to total and $>2-\mu \mathrm{m}$ net primary production in the global ocean and in the oligotrophic regions.

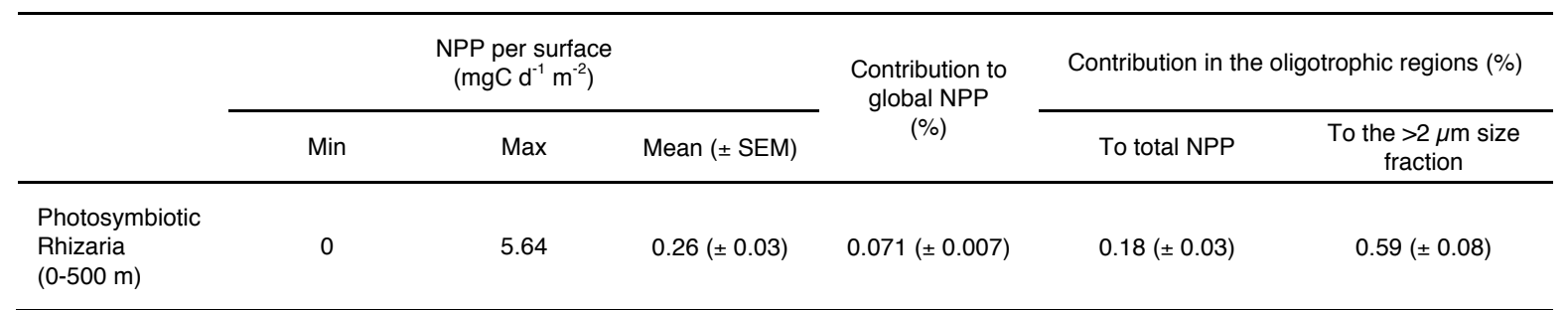

Global rhizarian NPP was derived from mean estimates $( \pm$ s.e.m., computed based on variation in rhizarian abundance in our dataset) assuming a total ocean surface of $3.61 \times 10^{14} \mathrm{~m}^{2}$ among which nearly $56 \%$ are considered oligotrophic (that is, $2.04 \times 10^{14} \mathrm{~m}^{2}$; ref. 6). The rhizarian NPP contribution to global and oligotrophic regions was calculated from total NPP estimates of $48.5 \mathrm{Pg} \mathrm{C}$ and $11 \mathrm{Pg} \mathrm{C}$ per year, respectively ${ }^{44}$. Contribution in the oligotrophic regions was estimated by extracting mean rhizarian NPP estimates in sampling stations where the $\mathrm{Chl} a_{\text {sat }}$ was $<0.1 \mathrm{mg} \mathrm{m}^{-3}$ (ref. 44). Contribution to the $>2-\mu \mathrm{m}$ size fraction assumed that picophytoplankton contributed up to $70 \%$ in oligotrophic regions ${ }^{45}$. 

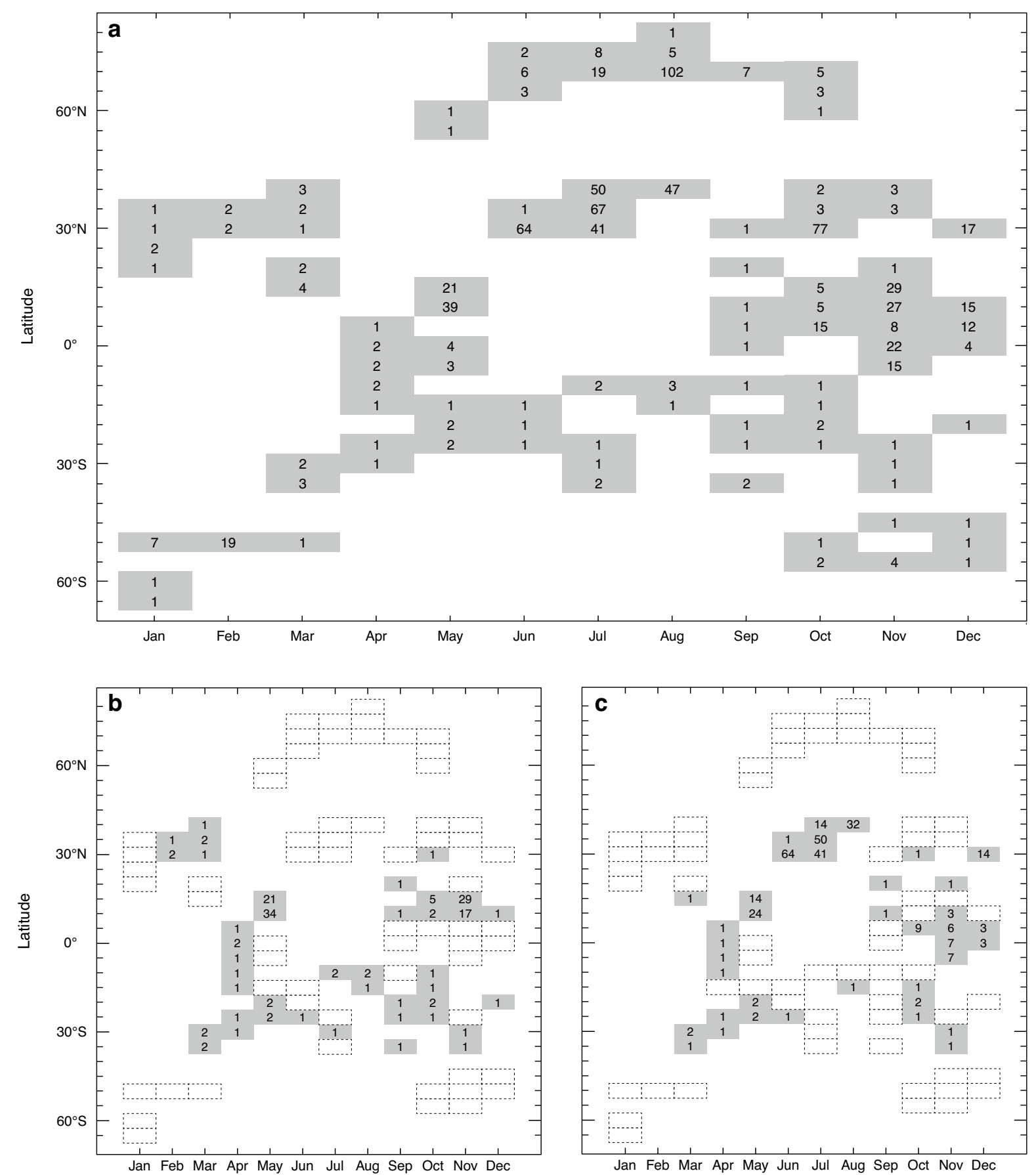

Extended Data Figure 1 | Sampling effort of the Underwater Vision Profiler surveys used in our study, represented across latitudes and months of the year. Rectangles identify latitude intervals of $5^{\circ}$ affiliated to a given month. Numbers inside rectangles indicate the number of stations sampled. a, Sampling effort for the full dataset. $\mathbf{b}$, Sampling stations identified as belonging to one of Longhurst's gyral biogeochemical province. c, Sampling stations identified as belonging to oligotrophic waters $\left(\mathrm{Chl} a_{\text {sat }}<0.1 \mathrm{mg} \mathrm{m}^{-3}\right.$; ref. 44$)$. White rectangles with dashed edges highlight the sampling stations not belonging to a gyre nor oligotrophic waters. 


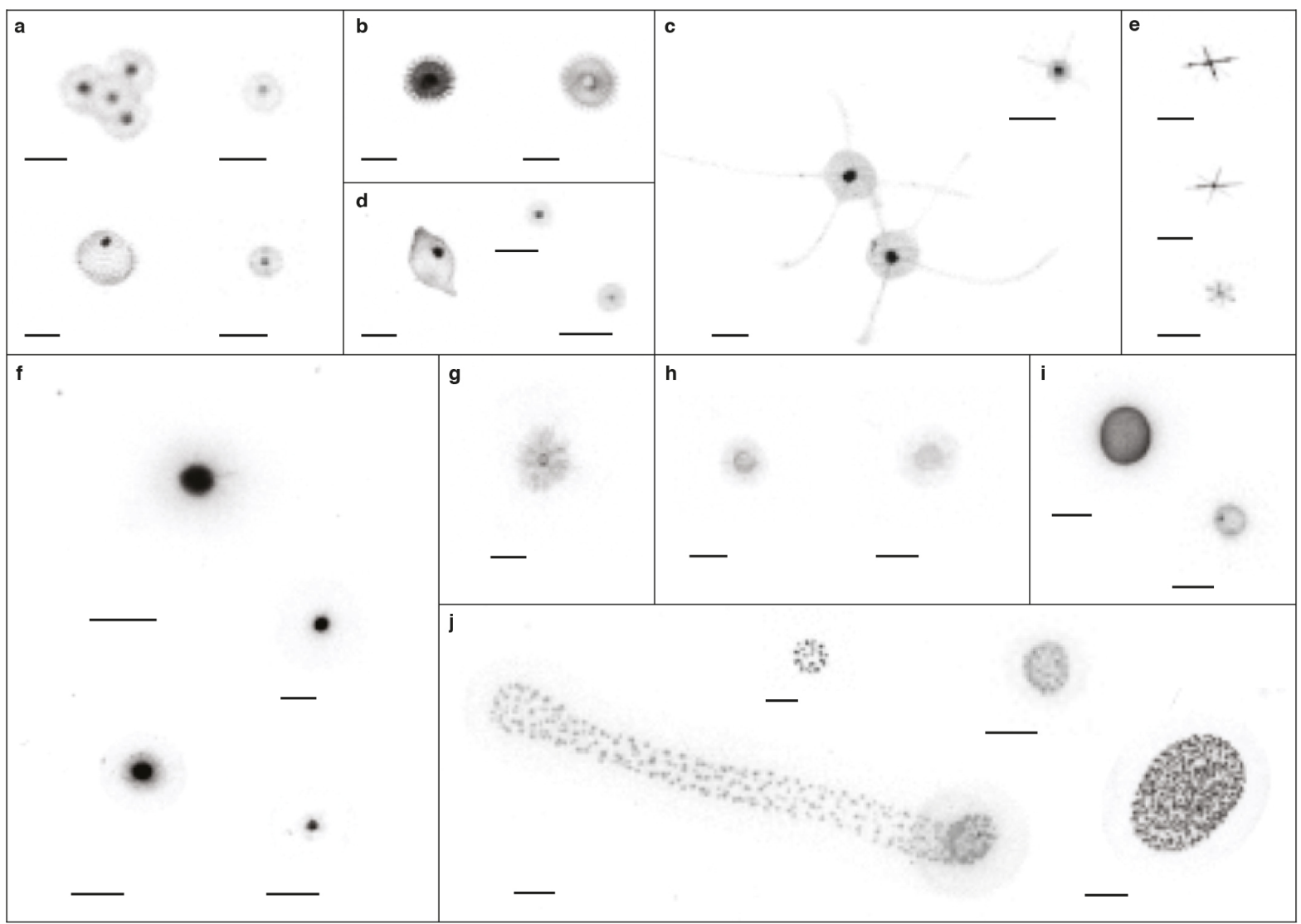

Extended Data Figure 2 | Images of the different rhizarian categories obtained with the UVP5. a-

c, Phaeodaria: (a) phaeodarian spheres (PhaSe), (b) phaeodarian spheres with thorn edges (PhaSt) and (c) phaeodarians with long extensions (PhaL). d, Unidentified rhizarians (Rhiz). e, Acantharia (Acn). f-j, Collodaria: (f) solitary collodarians with a dark central capsule (SolB), (g) solitary collodarians with a fuzzy central capsule (SolF), (h) solitary collodarians with a grey central capsule (SolG), (i) solitary collodarians with a globule-like appearance (SolGlob) and (j) colonial collodarians (Col). Detailed descriptions of the different categories are provided in the Methods. Scale bars, $2 \mathrm{~mm}$. 


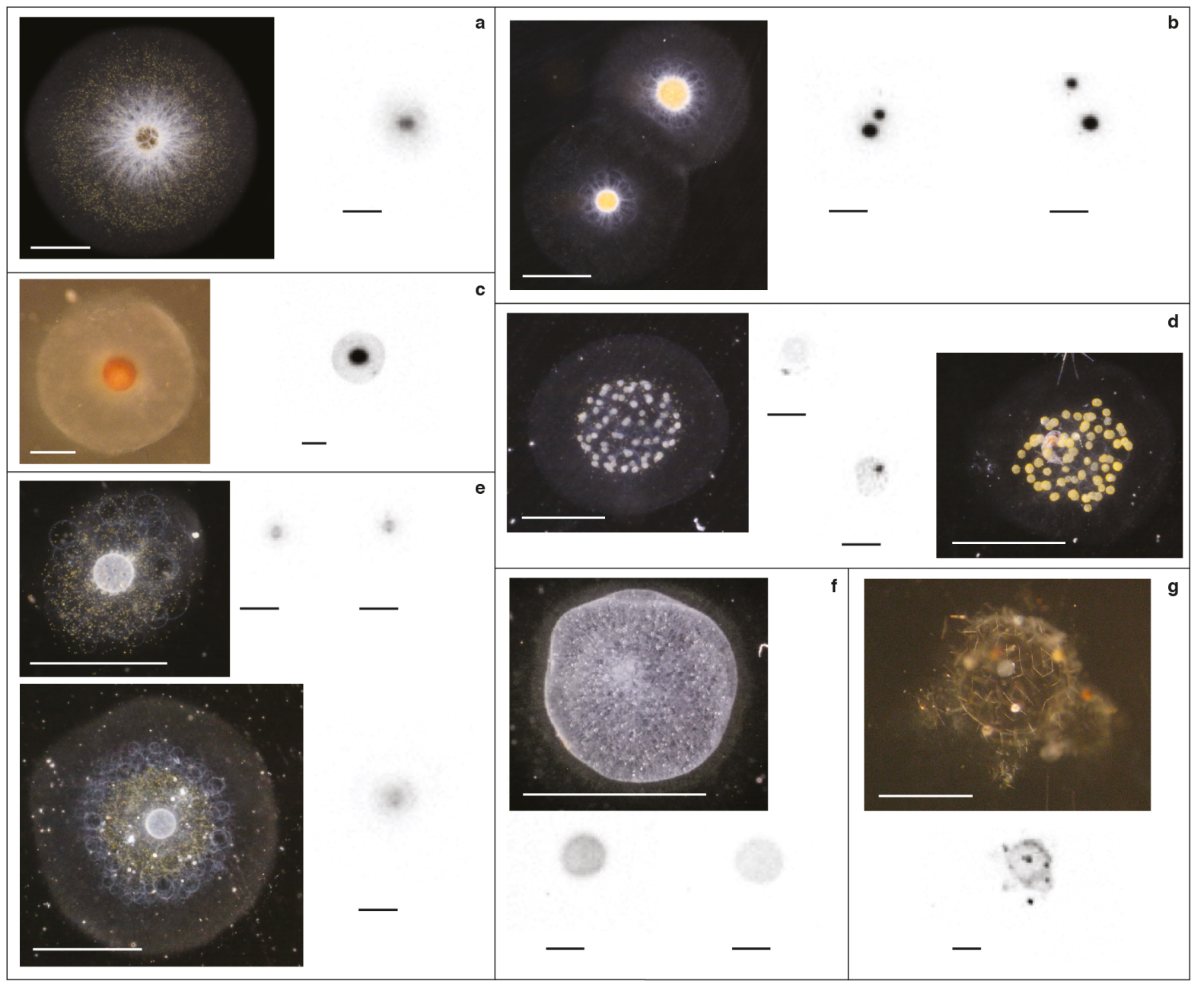

Extended Data Figure 3 | Calibration of rhizarian categories through comparison of single specimen images acquired by UVP5 and optical microscopy. Optical microscopy images and UVP5 images were obtained from the same specimens. a, Thalassicolla caerulea (SolB). b, c, Unidentified solitary collodarian species with dark central capsules (SolB). d, Small collodarian colonies (Col). e, Procyttarium primordialis (two solitary collodarians with a white central capsule; SolG). f, Physematium muelleri (a solitary collodarian with a granular and opaque surface, similar to SolG). g, The Phaeosphaeridae family of Phaeodaria (PhaSe). Scale bars, $2 \mathrm{~mm}$. 


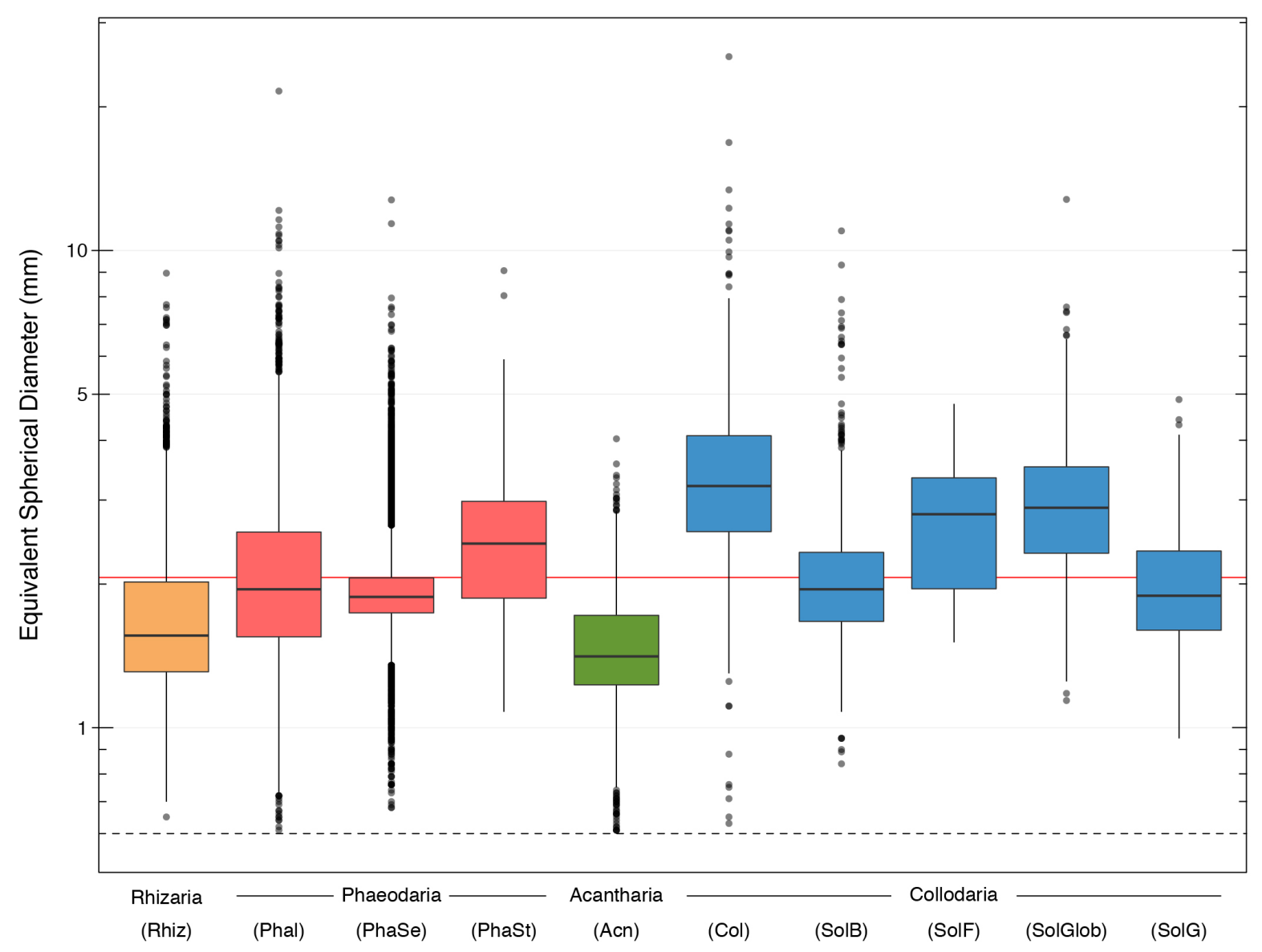

Extended Data Figure 4 | Size distribution of rhizarian categories in the UVP5 dataset. The dashed line represents the $600-\mu \mathrm{m}$ size threshold of the camera. The overall mean equivalent spherical diameter (ESD) is $2.06 \mathrm{~mm}$ (red line). Dark horizontal lines represent the mean, boxes represent the first and third quartiles for data distribution around the mean and the whiskers denote the lowest and highest values within 1.5 IQR from the first and third quartiles. Outlier values are represented by dots. 


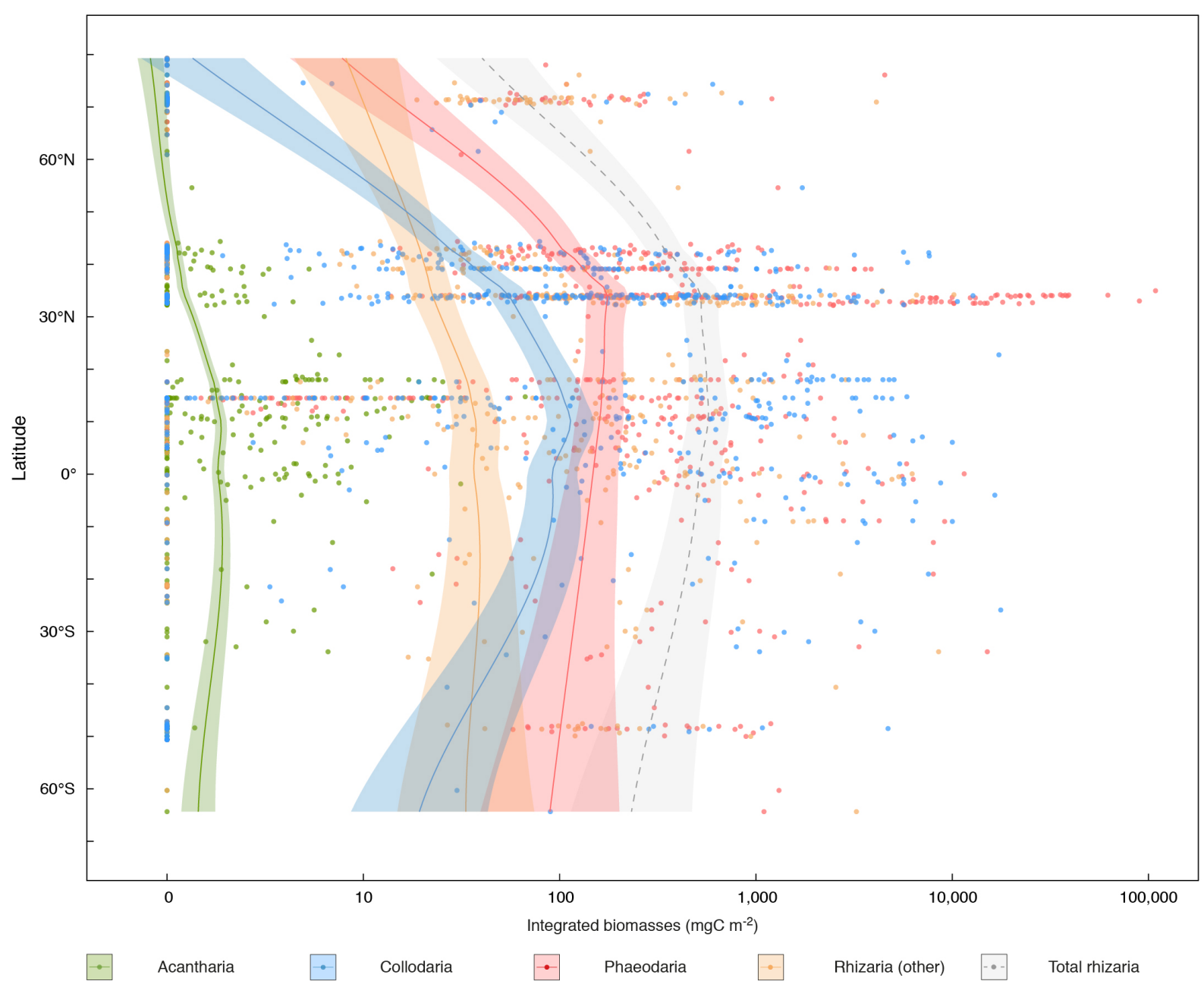

Extended Data Figure 5 | Latitudinal biomass distribution $\left(\mathrm{mg} \mathrm{C} \mathrm{m}^{-2}\right)$ of the different rhizarian taxa identified (Acantharia, Collodaria, Phaeodaria and other Rhizaria) integrated over the top $500 \mathrm{~m}$ of the oceans (694 sampling stations). Loess regressions with polynomial fitting were computed to illustrate the latitudinal trends. Shaded areas represent $95 \%$ confidence intervals. 


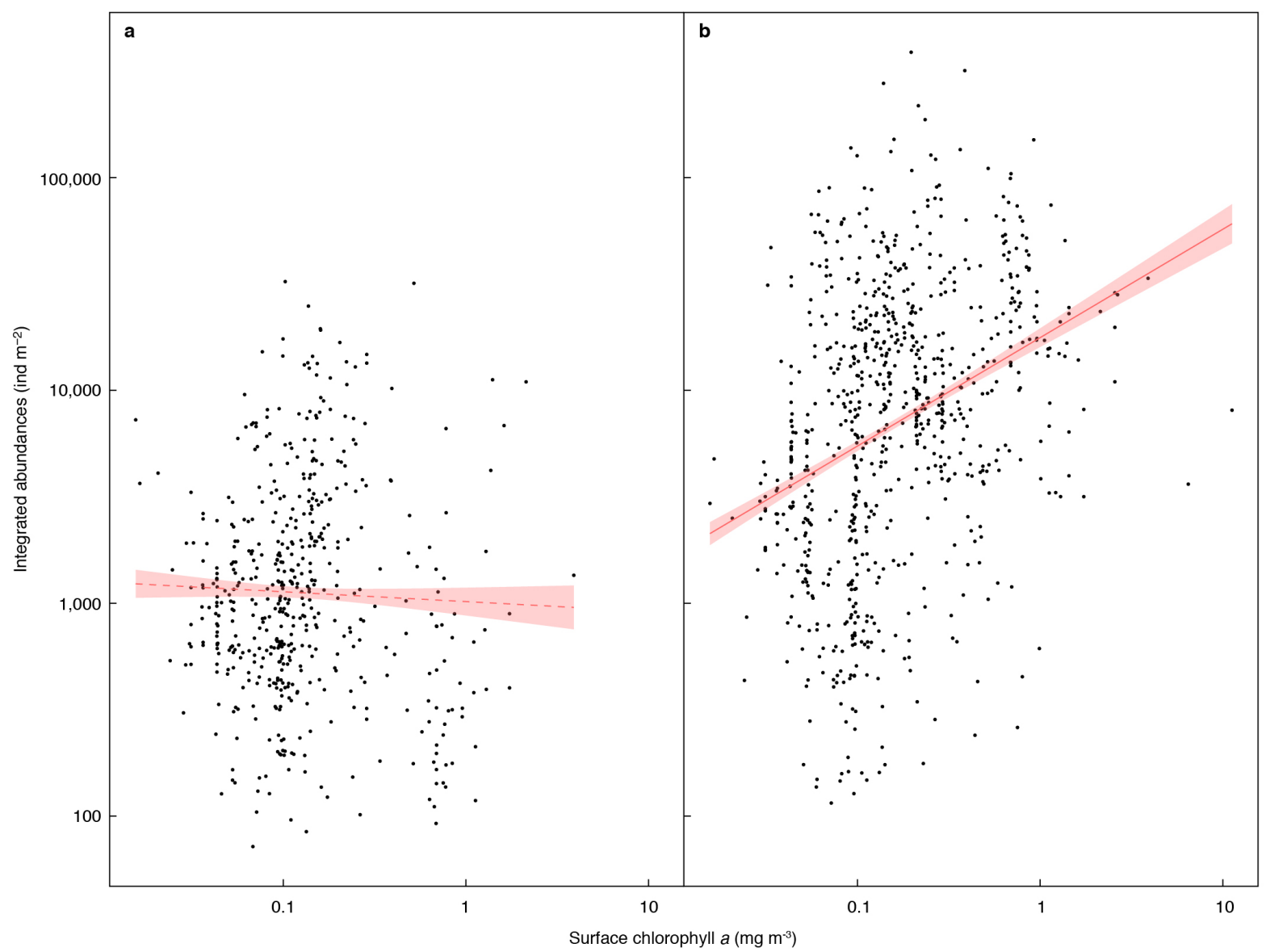

Extended Data Figure 6 | Variation in UVP5 depth-integrated abundances (0-100 m depth) as a function of the MODIS surface chlorophyll $a$ extracted from satellite data (Oregon University

Database). Solid and dashed red lines indicate significant and non-significant linear regressions, respectively. The shaded areas represent the standard error. a, The integrated abundance of photosymbiotic Rhizaria $(n=521)$ was not significantly linearly dependent on chlorophyll $a$ concentrations $\left(F=0.622, R^{2}\right.$ adj $\left.=-0.0007, P=0.431\right)$. We assume that all collodarian species are photosymbiotic ${ }^{13,14}$ and that the majority of large acantharian cells found in the photic layer are known to harbour symbionts ${ }^{24,25} \cdot \mathrm{b}$, The integrated abundance of other zooplankton (including asymbiotic Rhizaria; $n=793)$ decreased linearly along a trophic gradient $\left(F=94.51, R_{\text {adj }}^{2}=0.106, P<10^{-16}\right)$. 